\title{
Bigger They Are
}

BRIAN SAT WITHOUT MOVING IN THE DRIVER'S SEAT OF HIS RUINED truck wondering how he would get to town for the ceremony. Steam slipped hot over his eyelids. Something was wrong with his shoulder, a bloom deep in the joint. There'd been a moment when he saw it. Eyes on the yellow line. This cut-out antlered thing on the road's edge. Or had the creature been in the middle straddling the line? To the side? He hadn't swerved into it. His son's high school graduation began in two hours. Punch and snacks and merciful adulthood. Two hours. Dripping noises steady from the engine. Radiator ticks kept waking him up as he turned his head this way and that way and sat there in the cab. For some reason, he wanted it to rain.

The S-10's dash looked off, like something had shifted over the heat vents and gauges. The elk had caved in the truck's hood and left a hairlined ditch in the aluminum. In the rear-view he made out the front bumper some twenty feet back, buckled and spotted with skin and blood. The elk lay half on the road, half in the grass. Tongue way way out. The beast heaved loosely and looked skyward. Its body wouldn't do what it wanted. Both eyes would roll back, then refocus, roll back, refocus. An accident. Did an accident count? It would still fall to him. Perfect. Brian laughed, noticed how it sounded kind of hysterical. Blood peeled down his face from somewhere above his left 
eyebrow. Globs in his peripheral vision. Drip, pause, drip, drip, pause. Everything much too warm. He steadied himself with one arm against the door and opened it.

BRIAN WALKED OFF THE CINDERBLOCK STEPS of his house into the early night. The cinderblocks, relic of some stopgap instinct for any kind of ramp into his dwelling, always clicked. He wanted to crush them with a sledgehammer and make them into gravel for the driveway. His front yard lay like a moonscape of half-frozen mudholes, dead grass, and tire troughs. It looked abandoned in the greyness of everything. Each step, he sank into the muck. His boots felt weighted. He needed a deck, something to separate his front door from the woods. Esna hadn't yet returned from town with the groceries. She'd want him home by then, he knew.

Ruby had called around dinner time, said, Brian, I'm sorry to ask, but Penelope is dying. Could you come over? I wouldn't ask, but . . . And he said Okay, thinking But you did ask. What are neighbours for? He'd known Ruby for two years. She ran a therapeutic horse ranch for disabled people. Her fenced corral butted up to his acreage and they often helped each other out with construction or her animals. Barter system mostly. This for that. That for this.

Scraggly one-frost grass covered the yard, almost dead but not quite. He headed for his shed, stepped into the darker interior knowing where things were without needing to see. The old steel mining box was in the back corner next to the wood stove. He flipped open the hook-clasp and got the shotgun. Slugs were in a Winchester carton on the shelf above the mounted vice. Then he walked back out to the yard and away from his house down the beaten trail peppered with divots of frozen water. Wind curled through the pines with a sound like escaping steam.

Ruby had maybe four horses, maybe five or six. He couldn't be sure. There were a certain number of horses. Several might be visible wandering through the branchless trees at any one moment, but it never seemed like all.

Still autumn. Brian always felt just behind the Yukon seasons. Mid July, he'd noticed the dimming of each day. And in the core of 
winter with the ice fog and bitter dryness, days grew long in a sneaky procession towards summer. On and on he chased and never caught up.

A black horse came up alongside the fence, began to walk next to him, parallel. They navigated their respective sides of the four sometimes-electrically-charged wires. Desiccated cranberry bushes sank under his boots. The black horse followed him down the line tilting his head this way and that. The wind picked up further and whooshed through the trees.

This black horse was not the dying one. This horse made him feel like the dying one. The size of it. The way the horse's muscles slid against each other, he thought of a printing press, an old one, silky clockwork through the woods. Brian put his hand through the fence wires, hoping the electricity wasn't running. He patted the horse's warm flank, felt the groove between two ribs.

"Hey there," he said. "Aren't you pretty."

Past the corner post of the main corral, Ruby's property and house came into view. Two outbuildings and a barn, a smaller circular corral with a tie post in the centre. The property cluttered with bales of hay and burst hoses, rusted buckets, and loose wheels of twine blowing in the wind where they lay. Tall half-covered bags of grain and oats and piles of shit in various stages of becoming soil. One of the sheds had no door. Everything in some stage of construction or dissection. He went up the steps to her front door and knocked.

RUBy WASN'T SURE ABOUT ASKING BRIAN to do it. She worried it would change their responsibilities to each other. Somehow tilt their agreement.

Thunk. With her maple door, Ruby always knew how tight someone's fist was by the sound it made.

She'd called him, so he knew she was home, but he'd knocked, because they knocked, by some neighbourly rule, when they visited each other.

She opened the door.

"Brian," she said.

"Ruby." He gripped the top of the door. He'd propped the shotgun at a steep angle against the outer door frame, almost out of sight. 
She didn't acknowledge the gun. "Look at this wind."

A sharp gust flipped up the collar of Brian's thick coat.

"Getting colder," he said and nodded.

"Some frost this morning. Did you see the frost this morning?"

"Saw it on the greenhouse plastic. Crystal patterns."

"Thanks, you know."

"Least I could do."

"Well, we both know it's not the least. But, thanks all the same."

A pause. Ruby looked past Brian to her ragged lawn and the muck around her septic field.

"So." He indicated the corral. "Where is she?"

"In the trees." Ruby pointed toward the woods to the right of the house. "In there. You see?"

He pointed where she'd pointed. A denser copse of branchless pines. "Over there?"

"Right over there."

"I can find her." He nodded again.

"Sorry about this."

"I don't mind, you know."

"I said only the once. I know I did."

"Yeah." He exhaled. "You did. But it's okay."

"It's Penelope."

"Big light one?"

Tan. She wanted to say Tan. "Yes. The light one. The Palomino."

"And you're sure?"

Ruby nodded. "Swamp fever. Flu. I should call the vet. But I don't have the money. Trust that she's suffering plenty."

"It's kind of like that with horses, eh? Perfect or dead."

She wanted him to do it and leave. Do anything and leave.

"You want to come?" he said.

"No." She leaned against the coat rack. "You'll find her."

"Hide and seek, right?" he said. He made to turn.

"Brian?"

"Yeah?" 
"Did you know a horse's knee is the same as a human's wrist?"

His brow crinkled. Clouds had gathered, gone dark, mixed in with a brittle blue sunset.

"They sure need their knees," he said.

"It's just something."

"Okay. I'll get going." He made to go and again stopped. "Are you butchering her yourself? The body, I mean."

The body.

"I'm borrowing Morris's Bobcat," said Ruby. "I've got that organized. A pit grave, I think."

She needed a big pit. She'd tried mushers before, but felt weird about it. Dogs ate anything. She'd given a musher an entire horse (Baxter, broken leg from a gopher hole) and some weeks later she'd seen the musher at the liquor store downtown and asked about the horse, about the body, and he'd looked at her, confused, like he didn't even remember. The case of Heineken was more important. And then he'd kind of leered. A real idiot. When she reminded him, he gave this purse-lipped nod, said, The dogs went through it all pretty quick, but thanks. Any time you got one, you know my number, and looked at her like to say he'd be okay with fucking her, and the horse carcasses were more whatever happens, happens.

Brian turned and headed down the steps. She closed the door, but stayed in tight behind it, listening to his boots. Clomp Clomp. The third step down needed new nails; the bottom plank's right edge had rotted to mulch in the summer rains. Then he hit grass and she couldn't hear him anymore. Hide and seek.

BRIAN LOOMED AT THE TABLE with his breakfast plate and the mail: a half-black banana peel, mug with an inch of cold coffee visibly clouded by grounds, a plate of toast crumbs, pen and paper and statements and dotted lines. Bills. Ken played in his blue plastic crib. Brian always lugged the crib from the bedroom to the kitchen during the day; heavy, but worth it to have Ken out of that cold room.

Their wood stove wheezed when very hot. It had to do with the five-gallon pot of water they kept on it. Evaporation added some small 
moisture to the air in the house. He'd wake up in the night panicked with dehydration, red-skinned, sweating. Esna sleeping silently beside. That three in the morning cup of water saved him night after night. He'd started putting a cup in the fridge before he went to bed.

Ken's crib was something workable from the Salvation Army. Hed made Esna pick it up. It's the same if I go, she'd said, It's the same as if you went.

"Bahhumm," said Ken. His babbles had picked up in the past weeks, began to sound more like words. But was Bahh closer to Mom or Dad? Pa? Ma? A son saying Dad first and a daughter saying Mom first would be perfect. It would be fair.

Esna came from the bathroom hallway wrapped in a canary towel.

"I can feel the cold outside."

Drops of water trailed behind her as she walked.

"It's hot in here," he said.

Heat crawled outward from the wood stove, sank into his elbows and knees. He'd split wood for hours yesterday, done it until his elbows creaked and cramps dowelled his ribs. Set piles of kindling beside the door to save the walk to the woodshed. Always plan ahead.

"I know." She stepped behind him and rested her chin on the top of his head. "It's just the whiteness. It's so bright and so dark. Where are we?"

"I'll get rid of the windows."

"Sorry, I was reading Basho."

"The temperature is the temperature. Poetry won't keep the house warm."

She touched two fingers to the base of his neck.

"How was the shower?" Her third that day.

"Wet."

"Hot enough?"

"The wetness is just the wetness," she said.

"And probably something about the moon," he said low.

"Scalding." She rubbed her chin back and forth on his head and laughed.

It hurt. 
He'd never told her this, but he loved her most when she made fun of him.

The stove wheezed and wheezed, sometimes high-pitched, sometimes more of a wail. Standing, he put his arms around her waist. Her black hair hung down, a smooth stone wall. Her nose, this tinyholed pebble above her mouth. He rested his head in the crook of her neck. Strands of her hair tickled his nose, his eyelids. They stood for a few minutes, hugged close, reacquainting.

The month away in Ross River had stretched. The guys called it Lost Liver. Mining had picked up again at least. Thank God. Something about copper and gold, a whiff of uranium. Zinc here. Silver there. A contractor hired him to cut line. Good work, and hard, and away and so far away, and away from home. Yukon and mountains and winter; he always thought of it as being a soldier, but alone, and fighting nobody. In a war no one's ever heard of.

Esna worked days as a blood technician at Whitehorse General Hospital. Ken spent too much of his time in daycare. Esna took blood all day long, arm after arm. She said everyone bled differently. Some let out trickles or little pulsing red gasps. Some had one swollen drop. Some didn't bleed at all, their skin mending from the needle like magic.

And if they were eating dinner and talking, or next to each other in bed, he'd always say I'm lucky I don't do what you do, but really, he didn't feel anything particular about it. It was a job. They managed. But she wanted him home for Ken now, and he couldn't be home for Ken because Ken needed a home, and food, the line of credit, the mortgage, and always winter like this crux.

ESNA WALKED INTO THEIR BEDROOM still half wet in red silk pajamas. Black strands of hair dangled over her cheekbones and across her forehead. She unbuttoned the shirt, shrugged it down her back and to the floor. She hooked her thumbs in her bottoms' waistband and raised her eyebrows. One light push of the elastic over her hip bones and they spilled down her legs. She stood for a moment, the bottoms pooled around her feet like lava and looked at him with her head to the side. Her abdomen was always tilted one way. Expectant, devious, askew. A small nickel-sized bruise stood out below one breast. 
"Hey," he said.

"Hey back." She tiptoed to the bed. Goosebumps had popped up across her arms and ribs, long legs, the bow of her collar bones. Her flat shoulders tapering to points. It had been a cold winter. Stove dead. Ken at school. Mai asleep. The two of them in that small room. They kissed. He lay under the thick duvet still and she straddled him over the blanket. The weight of her legs pressed down from the other side. He spun her over, kicked at the blankets until they pulled away and began to slide over the edge of the bed. Now him on top of her, still separated by the blankets. Maddening. He pulled harder on the blanket, until he felt the warmth above her knee. With the one hand he gathered a fist of duvet and hauled it back over them. He touched her hair, smelled the lavender soap. Pale window light across her jaw. Then the blanket back over them, just them, wrapped loose and blind and he couldn't hear anything really except the rustle and some small sounds.

She was asleep, and he was almost asleep. He looked up at the white drywall ceiling. They needed to paint. Esna had colours in mind. Entire palettes and swatches and harmonic shadings; she'd come to him with these bright tabs of thick paper: brown, red, and white, then a different brown, red, and white; then blue, white, and pastel-blue; tan, red, and creamy beige. He didn't get any of it, but loved them because they were all perfect, and shed probably agonized over them. Don't pretend it doesn't matter was one thing he kept telling her. She wanted this elegance in things, and the nature of this want was that it could not matter. Significance made it less significant. A Japanese thing, or an Esna thing. Culture had claws. Her family had moved from Hokkaido to Vancouver in the sixties. And they truly did have to paint the cabin. Brian wanted Ken to see colours and think about how one thing could be different from another thing.

Last week he'd taken a bag of McIntosh apples from the fridge for his lunch on a day job loading a camp shipment of tents, food, chainsaws, axes. Hed held that bag of apples and looked at them for close to a minute, then taken them and examined them by touch. Perfect apples. Not one dent or bruise or caved-in pressure spot in the skin. Seven perfect apples from a Yukon grocery store. And how could that be? So he'd asked later that night in bed How do you buy apples? And she pretended, not only that they weren't perfect, but that she 
didn't know what he meant at all. A smile, though, or the intention of a smile, and he'd known. Do you look for a long time? he'd asked, and she stayed quiet, her face just visible in the light coming under the door, and finally said, Perfect apples are a bargain.

She wanted him to find different work. She didn't want to be alone in the cabin anymore. Not through winter. It's the dark, she said, it's everywhere. He told her, It's only dark at night, and got back a cool Yes, but it's always night.

Their legs touched under the blanket. This was what he wanted. The mining camp was old men, young men, vagabonds, and alcoholics, some few yuppies who needed money, and, yes, even good men who were quiet or loud or lost. And there were no women. Crew talked in the tents at night, or around the fire after the food was eaten and the cold had settled over everything. Always it strayed to women. They talked about girlfriends, old girlfriends, future girlfriends, dancers, peelers, pieces, real women. And they thanked God that none were at the camp to complicate things and slow them down.

They missed them terribly.

He couldn't think of one animal that gathered as groups of males and did not fight and maul each other. People talked about how male bears turned to cannibalism, gobbled each other or the newest generation of cubs or the mothers. And maybe that was it, out there alone in those dark mountains in dark tents. All the men in those camps, deep down, knew they should be killing each other, and for whatever reason, weren't.

BRIAN'S FATHER, LEON, HAD HAD HIS OWN THEORIES about killing. As a father, Leon's greatest strength, the thing Brian remembered him for, was telling the real truth. Of course, the truth as Leon saw it might just have been ethics twisted in the furnace of hand to hand combat that was his World War Two experience, but he meant what he said. He'd fought through Sicily and then the Italian mainland, and eventually come back to Hamilton with scars, an eye for some hard living, and an unfathomable grimace. 
Leon married a librarian and settled down on what could have been called a farm. Raised his two boys. They had horses and chickens. Brian's younger brother was named Jack. When Brian was eleven, Dad brought him and Jack into the yard, marched them up to the chicken coop, and showed them how to kill a chicken with one of the kitchen knives. Brian always remembered how his dad chewed the air as he killed that first chicken as an example, his mouth open then closed, tongue at work on something Brian couldn't figure. After the lesson, Leon made Brian kill five chickens by himself. Jack also killed five chickens, but seemingly didn't have to, or had done it in the past. Brian's dad did not expect Jack to kill them, was Brian's feeling that hot afternoon. That long afternoon in the dry yard, ground all kicked up by Jack's running around with a chicken in each hand. Thick blades of sun through the hanging dust. And Dad there looking on. Brian did just like he'd been told and cut the chicken's throat and drained the blood into the dirt at his feet. Made sure to hold the wings down tight. Dad said if you held the wings down tight a chicken would not panic. The feel of that warm russet chicken in his hands. And all Brian wanted was to not mind in the same way Jack did not mind. Jack ran around with the chickens in his hands pretending to be a plane. Jack buzzed and hummed and faked gunfire. Eventually Dad said Stop, and Jack stopped. Dad told Jack to go inside and clean up and the other boy looked dejected for it but obeyed.

Then only Brian sitting there with the dead chicken and his dad off to the side seeming to peer into the dust clouds.

His dad went over to the log bench near the barn, waved at him to come sit by him. Fairly splattered with the chicken blood, Brian went over and sat. His legs barely touched the ground and he couldn't get balanced, which was why he never sat on the log bench if he could help it.

"Son," his dad had said, "This killing here, it might not seem good, but it is. You did good."

He remembered nodding.

"Did you feel those chickens?"

"Yes."

"How did they feel?" 
"Hot."

"Good. That's good."

"They moved a lot."

"But then they stopped, right?"

"Yeah. Then they stopped."

"It's a start. Chickens are too stupid and small, but it's a start. You don't care about these chickens. In Italy, well you know what I've said about that, but in Italy, it was hard. That was real killing. I read something last week about how only one in five soldiers were willing to shoot an exposed enemy. And fuck if that doesn't make the rest of 'em cowards, but that one in five saved the world out there. One good man in five was all it took."

"How do they know?"

"They know, boy. They're all saying that wars are done. That's what they're saying: no more war. They said it after the first one, but this time they mean it. You won't have to go to war."

"I would go," Brian said. "If they said, I'd go." He didn't want to go, ever.

"War's a terrible thing, and I can't say I wish it on anyone, but it builds a man up. I've seen boys that came in green as rain. Scared to death. I tell you, those same boys a year later, the ones still around, were steel. And it takes about seven. Give or take. But around. Seven'll do it. Had a friend from Newfoundland by the name of William. He didn't know up from down out there in basic. We started the campaign around September in '43, and he ended up in this monastery in Sicily. This Godforsaken Monastery. Separated from his men. Never killed yet and all alone in that church full of fascists. He killed seven men to get out of there. Best soldier I knew."

"What happens?"

"The first one is hard. Second one, too. They're all hard up to seven. The rest just go by. Not saying you aren't brave. But you won't get that opportunity. I'm going to start relying on you with the horses from now on. And the cows, if we end up getting a couple. Jack, too, but also you. Jack's been good about this. Can you be good about it? I think you can. It's the closest thing we have. I'll show you how to work the gun this weekend. And you might love a dog, but killing a dog doesn't 
count, okay, because dogs, we love them, but they're like chickens, and I'll be damned if they ever count as humans. I want you to see the lesson."

"I can be good about it."

"I can do it, Sir."

"I can do it, Sir. May I go clean up for dinner?"

"Yes you can. Bring that knife in with you so it doesn't rust."

Jack had never spoken about it to Brian, so maybe Dad had only told him. But he doubted that. Maybe Jack had got to seven too quickly for it to matter.

Ruby WAited For Claire to Fall ASLEep before she started with the winter gear. It was necessary to wait until Claire stopped talking and her breathing settled. Claire the actress. She could fake sleep, and had faked sleep several times: to surprise Ruby with a birthday card, to sneak in on Ruby trying on clothes late at night, or to see what Ruby and her boyfriend were doing still awake back when they'd been together, or when they'd cut it off, but had a talk, or had another talk, or just called and agreed to meet in the bathtub and never speak of it again. Or even that one time she and Brian had a drink in the darkest part of November. One solitary drink, and luckily Claire was very young and still joyfully focused elsewhere in that way children are.

Moses, the black gelding, hadn't gotten up that morning from where he lay among the trees. Had stayed there on his side looking at her dully. Only eleven years old. No real signs of laminitis until that year. But it had progressed. There, then not, then back again with its particular agony. Moses had broken into the feed bin a few times, true. That was her fault. A loose shed door. A glut of carbohydraterich food could do it. A horse's hooves are like giant fingernails. When they got bad, it would be like balancing your entire body weight on a fingernail that has been hit with a hammer. Moses hadn't gotten up in the morning, just sprawled there. He whinnied as she brought him oats. Accusingly, she thought. The big watery eyes had wanted her to do something, pick him up, set him right. 
RUBY HAD ON HER KNEE-LENGTH DOWN COAT, mitts, neck-warmer, toque, thermal underwear, boots. Wearing all of it inside was too much. Sweat had begun to fall down her back, actual drops she felt at the base of her spine. She hurried to the door and cracked it open just enough to slip out into the darkness. Ice crystals in the air reflected little pinpricks of porchlight across the black backdrop of the yard.

Brian was waiting for her at the bottom of the steps.

"Hey," he said.

"I'm sorry. It's late."

He nodded and followed her as she headed away from the house. They walked across the yard and stopped beside the white pipe-top marking the septic field.

Brian had the shotgun against his shoulder.

"Cold," he said, his face almost obscured by the cloud of his breath. She hunched deeper into her neck-warmer. "It's Moses."

"I saw him lying near the fence. I never knew his name."

"So you know where he is?"

"Yeah." He huffed another big cloud out. "Moses is a funny name."

"It's his foot."

"Just that?"

"It's pressure on the coffin bone, and damaged blood vessels to the front hooves; acidity in the nutrients." She hated badly organized reasons. The gun made her nervous. She trusted him, but it made her nervous.

"The coffin bone," he said to no one.

"He can't stand." She blinked in the cold. "Yeah, the coffin bone."

"Claire's asleep?"

Ruby nodded.

"Okay."

"Thanks for this."

He blew a stream of vapour out his nose. "And what do you tell her?"

Ruby paused and tugged at the band of her mitt. "I tell her someone needed him, and came to get him, and that he's gone. That's what I tell her." 
Brian grimaced slightly. "My dad never told me anything like that."

"My dad said they were on vacation." Her lungs burned each time she breathed in. Ruby watched the frost on Brian's eyelashes, the white fragments and ice patterns. Frost had begun to build up on the tips of her hair that swooped forward from her toque.

"And about my brother picking up the horse?" he said. "That's all good?"

"Yeah. After you-you know, after-can you put him in the barn with the loader?" She'd rented one. It was expensive.

"Won't that wake Claire up?"

"No, it'll be okay. You said you didn't want the body to freeze."

"Yeah, Jack said it would be better if it didn't freeze."

"The barn's a lot warmer since I got that new door installed."

Brian nodded, curled his dry cracked lip back over his front teeth. They were white and straight, except the broken one at the side. How could he expose that nerve to minus forty?

"He's coming by at six in the morning," said Brian. "We'll load the horse into his truck and go, quick as we can."

"Thanks for this, you know. It's a lot of work."

"Jacky needs the horse, so it's both ways."

"Both ways. Yeah. Night."

She walked across the crunchy snow, up the stairs and back inside. She watched him from the window until he left the circle of light.

The COLD SEePed up through the BOtTom of Brian's boots. He'd forgotten to dry his liners, and now they oozed icy water into his socks. He crouched and wrestler-stepped through the fence wires. Current off. Nothing to contain anymore. Moses was there somewhere. Out in the stripped pines. Light from Ruby's wall-mounted spotlight the area's only illumination. The brightness penetrated deep into the corral, shone off the hard, claylike ground cover of mixed snow and ice. Like Mars with thin black trees. Sharp fans of tree-shadow, motes of floating ice, the hard bite of cold at his ears as he walked deeper into the dark.

Brian heard it first. Gumming sounds. Big breathing. Giant something out of sight. 
Some of the light drew a shape, a few lines of white on black flank. Moses. The fallen horse looked at Brian with huge welling eyes. The animal's front legs splayed unnaturally, like splinters.

"Hey there. Hey there." Soothing. Warm and soft.

He considered circling around. He cracked the breach of the shotgun and slotted in one of the red slugs. The gun snapped shut with a heavy click. Safety off. He walked around back, in a kind of sidestep, just friendly and unthreatening, moved between some trees and over stumps until he stood behind Moses's head. Brian couldn't remember if horses even had a blind spot. Their field of vision would be huge. Moses on his side in the dark cold woods. It seemed like a song from somewhere. The next line would go And Brian only did what he could.

BRIAN SAT AT THE TABle With a PINT GLASS of coffee. Getting the horse into the barn hadn't been easy. Had he really thought picking up a twelve-hundred pound body with a power loader and navigating a rough trail to a barn would be easy? Even with the hydraulics doing the work, he'd felt the weight of the horse, the legs dangling over the blade, unwilling to be moved, the unfamiliar machine controls.

And unlike the others, Moses had not died so pretty and quiet. Everything the same as the times before-under the ear, pull the trigger, close eyes for the bang, refocus, get moving-that was how it always went. But Moses hadn't died when the shotgun slug flew through his brain. Hed spasmed and bucked, thrashed his thick neck back and forth like a serpent. And Brian had looked around from his black corner of trees, panicked that someone had seen him out there in the midnight woods, that someone had witnessed or watched or caught him. Maybe Ruby could see in the dark, or Esna might have followed him into the corral, crept from tree shadow to tree shadow, watched him do it and not said anything.

The next shot had done it. Moses was the fifth horse.

He sat with his coffee and waited for Jack. Jack was younger by two years. It was strange how that mattered less the less time they spent together. 
Brian hadn't seen much of Jack since August. He never saw much of him anyway, but this winter Jack had picked up trapping with an old native guy as his teacher. Brian wasn't sure what their agreement was. Jack had called about it a few times, his breath fast in the receiver, going on about an animal that hed just skinned. How its fat layers separated differently from its skin than the fat layers of some other animal. Coyote, wolf, wolverine, marten, lynx. All those different fat layers and skin and just those glaring differences in how they separated. Brian agreed and congratulated, and sometimes made jokes about the animals not really needing their skins, not truly. But he didn't think he could do that himself, peel the skin off with a knife.

Little hands grabbed his shoulder. "Hi, Dad."

Ken.

"It's early, bud." Brian put his hands over Ken's hands.

"I know," said Ken, slipping free. "I'm cold." He came around and sat cross-legged on a kitchen chair. Hed brought a blanket with him and wrapped it over his legs.

"You need another blanket?"

"No, I'll just wake up. Where are you going?"

"To help Uncle Jack with some things."

"What things?"

"Things at his cabin."

"Construction?"

"Kind of like construction."

"Can you make me toast?"

Brian stood and went to the cupboards, collected knife, plate and bread. "What do you want on it?"

"I want butter, and then peanut butter, and some honey on top."

"Honey?"

"Mom said I could have one honey toast a day."

"And you want it now?"

"Yes."

"Then one honey toast it is." 
Ken stayed at the table and started flipping through the newspaper from the day before. Almost eight years old. For a kid, he seemed serious.

"What are you reading, Kenny?"

"Ken, Dad. Just Ken."

"What's wrong with Kenny?"

"You call Mai, Mimi. She likes Mimi. But I'm Ken."

"How's school?"

"One of the boys called me a fag for going to aikido, but school's good." He said it quickly, but Brian noticed the question underneath, the not-wanting-to-seem-bothered thing Ken did so well.

"Who called you that?"

"What is a fag? I don't get it."

"Who did that?"

"Brad."

"If he does it again, you tell your teacher."

"I was trying to explain blending."

"Blending?

"Sensei was talking about it. I don't really get it."

"But you said you were explaining it?"

And here Ken rolled his eyes. "Well, explaining. I was trying."

"Okay. Okay. Practice on me."

"It's like, you have the uke coming at you, and you are the nage, and you ... blend with their attack and use the energy to go another direction." Ken gestured with his hands, moving them back and forth in wave motions. "I'm not explaining it right."

"No, I get it, that's good." He didn't.

"It's like, you join with the attacker and send the energy past you. It's about joining."

"So are you even fighting?"

"Yes, Dad. You are fighting. And Kyle, my friend, he understands, but I was trying to tell Brad and Lucas and Sean, and then Brad said 'You're a fag,' and what is that?' 
The toast popped, brown and perhaps too brown-Esna always set the toaster to its maximum level-but Brian stayed the course and buttered and peanut-buttered and honeyed.

"It's not important, Ken. It's a bad word and you shouldn't say it." He carried the plate over. "Here's the toast. Blending sounds just fine." He considered showing this Brad kid how to improperly blend.

"Couldn't we just not tell Mommy about this toast, and then I could have another toast later?"

"But then why have the rule?"

"Rules are," Ken nodded vigorously, "good and everything. But, maybe we could not tell only this once?"

Brian sat down at the table next to Ken. He stared out the window into the still-dark yard; it felt like night. Snow lay in a crust over anything left for more than a week. Every morning felt like hed mistakenly woken up at the wrong time. He put his hand on Ken's shoulder. "How about, just this once, we don't tell her. But you'll have to brush your teeth really good because Mom will taste that honey if she kisses you."

"I'll brush for five minutes."

Jack's truck clanked and thrummed in the driveway.

"Well there's Jack."

"Can I say hi?" Ken sucked on a corner of toast.

"Not today."

Ken just hummed to himself, lost in the treat.

Brian suited up for the cold and got his boots. The end of warm kitchens and toast. They'd have to get the horse in the truck quiet as they could. Hopefully it hadn't frozen too much in Ruby's barn. He imagined the horse breaking in half like some kind of stiff pepperoni. That sound would be something.

Once dressed, Brian watched Jack through the window. Jack had parked the old truck and sat in the cab looking straight ahead at seemingly nothing. Originally red, the old F-250 had rusted to a mixture of grey and penny-brown, its doors and bumpers sharp-edged and eaten away.

Finally, Jack got out of the cab, but didn't come inside, just walked around the yard and inspected the shed door and kicked at a stump 
and soon lit a cigarette and stood beside his truck peering through the trees toward Ruby's place.

"Bye, Ken. Remember your teeth."

Ken waved and continued to eat.

Hot air billowed from the house when Brian opened the door. Visible heat waves. He slammed the door behind him. It burned to breathe. "Jack," he said by way of greeting.

"Hey, brother. We ready?" Jack stepped from one foot to the other, almost jumping.

"Should I bring anything?"

"I got some machetes and the axe. Pepsi. Cheese."

The essentials.

"She lives up the road."

"Sure." Jack hopped back in the truck.

Brian got in the passenger side. Truck smelled like animals. Fur everywhere.

"Cheese is in the glove compartment." Jack had another cigarette lit.

"I had something already."

Jack started the truck but didn't put it into gear. "How big's the horse?"

"Big."

"Black or white?"

"Black."

"They're nice, eh? Those big black ones."

"Maybe it's brown."

"I'm lucky like that."

"Sure thing."

Jack pulled out of the driveway and turned up the road.

"I fucking ... missed or something with the first shot." Brian had dreamed about the kicking black legs.

"How do you figure?" said Jack not seeming too concerned.

"I don't know. I put the slug in behind his ear, and it just . . . they always go quiet right away, but not this one. He kicked his legs around and went all crazy." 
"It happens."

"But why? Left here." Brian pointed out Ruby's driveway.

"With animals," started Jack with a tightening of his eyes, "it's 'cause their, whatever it is, their fucking spirit gets confused and thinks

it's gone over to wherever, but it's still in the body. So it thrashes around until it gets out."

"That's how it is?" said Brian.

"Yeah," said Jack. "Everything's a maybe with dying."

"Horse is in the barn," said Brian.

"Can I drive across the yard and back her up?"

"Yeah, but keep quiet."

"Why? She think he's still alive?"

"She's got a little girl."

JACK'S CABIN SAT A HUNDRED METRES OFF Tagish Lake, deep in the woods, but with trails cut down to the shore. It had a square cast iron wood stove in the corner. Everything seemed damaged and just perfectly fine: the scarred pine table, the soot covered chairs. They drank stove-top coffee inside before readying to leave.

The toboggan must've been ten feet long and six wide. Jack dug around in the powdery snow, found a rope, and heaved the sled over to the tailgate of the truck. They had two snowmobiles for this. Polaris 700s. Jack spent a lot of money on machines. One of them had a winch and Jack unlocked it and triggered it to unwind. As the cable coiled in the snow, Jack walked it back to the horse. Once enough had been let out, he wrapped it around Moses's ribs and hooked the line on the other side.

"What are we doing?" said Brian.

"Well, I'm not driving this truck across the lake. He's too heavy for us to pull him out of the box."

"Is the winch strong enough?"

"It should do," said Jack. "It's going to cut him up some. No helping it." 
"What are cuts?" Brian felt himself falling into this semi-heartless back and forth thing they used to always do with roadkill back in Ontario.

"It's just a winch cable, you know? It bites," said Jack with a crazy smirk. Yeah, Jack remembered. Jack cinched the cable loop around the horse's ribs. Before starting the sled, though, Jack leapt up into the box, walked over and knelt down beside Moses's head. "Winch cables! They bite all the time, Mr. Horse."

"Yeah, they bite .350," said Brian.

Jack pantomimed swinging a bat with the cable end. "This cable is Bobby fucking Avila."

Digging with a gloved hand, Jack peeled back one of Moses's frozen eyelids. The eye had whitened in death and leaked yellow mucus from the tear ducts. "Do we have your consent, horse?"

"Did you call his lawyer?" said Brian.

"I talked to him," said Jack and he patted the horse's thick neck. "And this lawyer of yours, horse, let me tell you, I'm sorry, but he said we could take you for a ride." He leapt from the back of the truck and headed for the snowmobile on the other end of the winch.

Brian didn't much like winches. He'd seen a guy in high school get his hand yanked into one while pulling stumps. That thing had sucked two fingers right off the kid's hand.

The whir of the winch started up when Jack hit the return button. The skidoo lurched towards the truck.

Jack turned the winch off. "We need more weight."

Brian ran over, tied the machine to a spruce, then jumped on the back.

Jack rattled a laugh through his cigarette. "Just need to get part of him off the end." Jack re-engaged the winch. For some seconds the cable went taut, the snowmobile lurched and dug forward, pulling on the tree as the truck sank back on its suspension. But eventually, and with a rough sliding sound, Moses was pulled off the tailgate to crash down on the waiting toboggan. 
OfF THEY WENT ACROSS THE ICE. This dead-horse procession. Jack had agreed to tow the toboggan, so Brian played around on his machine, gunned it across the deep open snow, carved, opened the throttle all the way for a few seconds until he got spooked about crashing into a hidden bank of ice. He kept Jack in sight through all this, not wanting to get lost, though a dead black horse on a frozen lake was a hard thing to lose.

They rode until open ice transitioned to shore ice and then just snow and small endless pine trees at the base of the mountains. This was the very bottom of the trapline Jack was using. This was where they could turn Moses into wolf bait.

They stopped and ate some of the smoked cheese. Shared a thermos of black tea. Brian didn't look at Moses. Frost had coated the horse by this point. At least he thought it was frost, or condensation, though it could have been death fluids that he didn't know about, and they were leaking out and freezing on the hair.

"This is good cheese, Jack."

"Smoked it myself."

"What kind?"

"Maple shavings."

"So it should taste like maple?"

"It's just the smoke, really. It's like that shit people pretend is in wine. You know, mountains and berries." Jack cut a wedge from the cheese. The wheel had a dark brown rind from the smoking process, a thick layer of this different taste. Like the smoke had transformed some small part of the cheese into meat.

"Never butchered a horse." Brian didn't want to be nervous about it. He kept thinking that Ruby could see them, that she had a special telescope or just one of those feelings. Yes, he'd told her what Jack needed the body for, but he'd spoken in generalities, and there, on the lakeshore with that smoked cheese, things had specified.

"It's easy," said Jack. "See how he's on his back, legs all up?"

"Yeah."

"Okay." Jack stood and wrapped the cheese back up. "Here, I'll show you. You had enough?" He held up the bundled wheel like an offering. 
"No more."

Jack took out one of the long machetes. The flat of the blade was coated in black and what looked to be smoke marks or tar. But the edge had a new gleam, one of those rough sharpnesses, an edge done by hand with a file. The machete's original handle had been replaced by a dark wood custom job carved with flowers. Were they flowers? There didn't seem to be any particular image, just stems and leaves and maybe some petals, but he couldn't be sure.

Jack high-stepped through the snow over to the horse and got on his knees beside the front leg. "You see this?" He pointed at the spot where the foreleg joined the main body.

"The armpit?" said Brian.

"I guess you could say armpit." Jack shrugged. "Smells like old spice."

"So, you chop down here." Jack stood and swung the machete in a big arc that ended in the horse's armpit. A sound like digging a hole. Most of the blade disappeared and semi-frozen blood oozed around the blade onto the snow like yogurt or a popsicle left in the sun. Jack cut again, and again, and once more. The leg fell sideways and into the snow, still attached by some threads of skin. "See?" said Jack. "Get the other blade and do the back legs."

Brian found the other machete, also old and sharp but without the carved handle. The back legs looked massive up close. The biggest legs Brian had ever seen. Moses's penis was nowhere in sight and Brian hoped it wasn't part of the job. Jack had gone around to the other side and begun on the other leg. So Brian lifted the blade and swung. He didn't swing as hard as Jack had, almost like to make sure the horse wouldn't mind. It's dead, he thought. Dead. Very far away and hopefully not hovering over them. So he swung again, worked the blade down through the thick frozen muscles, the tendons, the bone. He couldn't cut the femur. He knew boning was something different, a different skill than just cutting. Bones liked being in their proper joints. He tried working the tip of the machete blade around the inside of the socket, but the tendons wouldn't separate. The angle was wrong. The machete kept skipping. Clonk, Clonk. Jack came over with the axe, and Brian tried that instead. It crushed whatever it didn't cut. He swung and swung, and finished the leg, then went to the other. Sweat ran down his 
neck; a spill along his back, and from his armpits along his ribs. Jack watched him and smoked. Brian dropped the axe and took a moment to breathe, his hands on his thighs. Soon all four legs were splayed out to the side.

"If that ain't the prettiest snow angel I ever did see," said Jack. "Snow angel," Jack sang with his gravelly voice, "Snow angel ... the one I adore." He swung the axe into the neck. "What's that song again?"

"That's not the song. It's Earth Angel."

"Snow angel... Snow angel ... will you be mine?"

Brian stood in the sun and stared back across the lake while Jack sang and cut the head off. What size of meat did wolves like? Fist sized? Basketball sized? He hadn't thought of it before. They had more cutting to do. Strange how cutting had almost disappeared from the world, as a skill. What a thing to go. He knew the slaughterhouses used robots for the most part, or band saws, or gigantic spinning cauldrons of some sort where everything is sharp. Soldiers used guns if they had any. Butchers were dying off. And the whole messy thing did look like a goddamn snow angel. Grisly, and too-red on the snow, and too-black on the snow, and mostly it looked like some nasty ritual, which maybe it was exactly that.

A WeEk Since Brian had taken Moses, and Ruby agreed to join his family for dinner. The dinner felt kind of like wrapping up a business arrangement. String beans and carrots steamed from clay pots on the wooden table. There was a small dish of pasta for the kids. Ruby sipped cold milk.

Steaks hissed on the stove and the air had semi filled with smoke but no one commented on it.

Little Mai was asleep apparently and not at the table. Too bad. Ruby wanted to see her, hold her up, judge and appraise, kiss her downy cheeks. She probably looked like her mother, which meant she'd do fine. Esna didn't speak much, just demurely went about her business of listening. Brian talked about his work in mining, which camps hed been to, his sore lower back. Sciatica.

Ruby felt like something had hidden itself under the table. 
Ken was eight, and two years older than Claire, but they knew each other even though they'd never really done play dates or anything. They made faces at each other from across the table.

"You know what?" said Claire with a forkful of pasta hanging near her mouth.

"What?" said Ken. He sat cross-legged on his chair like a small concerned yogi.

"Our horse, Moses, is gone."

Brian stopped talking. They all did.

"What do you mean?" said Ken.

"Well," said Claire, slight quivering drama in her voice, "someone came to take him, and then he was taken away. So he's gone."

Ken squinted and scratched his neck. Ruby saw this. She saw Ken trying to navigate what he suspected was a delicate social situation regarding death that he didn't fully understand. He'd grown up a lot since she'd last seen him.

"So, he's gone?" said Ken. His tone lower now.

A string of cheese dangled from Claire's mouth. "Yeah. Gone."

"Do you know who took him?" said Brian finally.

"It's not important," said Ruby. She needed calm, she needed whimsical.

"Do you know who took him?" said Claire, turning to look at Brian suddenly.

"He's a very big man," said Brian. He paused and stared at his plate then back up at Claire. "Let me tell you, Claire, he's as big as a house. $\mathrm{He}$ has this backpack that he carries everywhere. This pack of his is large enough that he can carry a piano or a cow and just keep on walking. He walks everywhere."

"Are you lying?"

Claire's eyes had this expectation for proof that there was more. Like despite every indication to the contrary, the world shed been shown was still only one way of doing things.

"And when he's walking," said Brian, "when he's walking in the forest, he might find a dog, or a horse, or even a person, and the person might not even see him, but maybe they do, and so they have a talk, just the two of them. This giant, he asks this person or horse or dog, he 
says: I could take you the rest of the way? and if they say Yes, he picks them up in his huge hand-his hand's like a boat- and puts them in the backpack. And off they go together."

"What if they say no?" said Claire, her eyes wet at each corner.

"If they say no, he just nods his head once, and walks on by, mostly."

"Is the backpack big enough for Moses?"

Ruby suspected she had a terrible look on her face, one that you can't even feel, and not knowing you have it is the reason it is so terrible.

"It's big enough for two of him."

And the steaks were ready. Ruby's bled on the plate. She'd asked for it rare. Blood and grease pooled in the middle of her plate. She sopped it up with a heel of garlic toast. Esna seemed to be staring at her as she did this. Ruby kept at it, running the garlic bread back and forth until it grew scarlet and looked like thigh. She ate the bread in one bite, washed down the rest of her milk, and winked at Esna. She shouldn't have, but she did.

"Mom?" asked Claire as they walked along the trail beside the horse fence. The snow had gone brittle and loud.

"Hm?"

"Well, Brian says the big man will carry you the rest of the way, but the rest of the way what?"

"What?"

"He says he'll carry you the rest of the way, but what way? What way, Mommy?"

"It's a big trip", she said, too loudly for the quiet forest. "Okay, Claire? A big, big vacation. You heard what he said. You're in the backpack and he walks everywhere."

"It sounds scary, I think." Claire grabbed Ruby's hand.

"It sounds okay, I think."

Near the end of trail, Claire let go of Ruby's hand and plopped down on her belly in the snow.

"Claire, it's bedtime. Let's go." 
Claire didn't answer, had the side of her head against a patch of frozen mud.

"Claire? What are you doing? You'll get an infection."

"Wait."

"Why?"

"I’m listening for his footsteps."

WhiteHORSE HAD NO PERMANENT tuxedo store-few people wanted or had a use for tuxedos-and so Brian and Ken stood in among portable steel racks of tuxedos and tall portable mirrors on wheels; it was an almost empty warehouse space in what used to be a kids' playplace in Riverdale. A Vancouver company, Aces Suited, set the thing up for May and June of every year to cash in on desperate parents of high school students. Beyond jackets, they rented shirts, pants, vests, even shoes.

Brian stood behind Ken at a fitting station. Ken peered into the three tall mirrors arranged at different angles. This suit: a black Calvin Klein, red vest, fitted.

"It's nice," said Brian.

"I told you fitted was in."

The suit hugged Ken's slim frame, made him look way too adult.

Ken did a few steps forward and steps back. Turned to the side. The other side.

"I think this is the one," said Ken.

"You sure?" Brian knew he was sure; Ken never even tentatively chose something without being entirely sure he wanted it. Brian wanted to stay there, in among the racks of tuxedos, for a few more hours if possible, soak it up.

"I think this is the one," said Ken. "It's two hundred and fifty bucks."

Ken turned his head and checked if that was acceptable.

"Okay," said Brian.

"It's literally the most expensive one, Dad. I can get something else." 
"You didn't plan it to be the most expensive one; it just is. It's nice."

"It's damn nice." Ken did another step forward.

"Does Christine have something red to go with the vest?"

"Her dress has some red."

"Let's call that guy over."

Ken did a quick sideways dance thing that made him look to be gliding along the floor. He liked hip hop now.

"Practising?" said Brian.

"It wouldn't look cool if I was practising."

"It looked pretty cool."

"I look deadly in this thing."

"Deadly is a thing?"

"Deadly is always a thing."

"Glad we're only renting," said Brian, half joking.

"Do you know how much this would be?" Ken smirked into the mirror. Ken seemed to know the price of everything these days: shoes, shirts, headphones, jackets.

"How much?"

"With the shoes, like eighteen."

He also only said the first part of the number of any price, as if the zeros were obvious.

"Eighteen hundred dollars?"

"I mean, it's beautiful," said Ken, in this weird, manly educated way he'd started doing after Christmas. "But, yeah, it's a bit pricey."

Brian put his hand on Ken's shoulder. "It's nice fabric." He let the hand stay.

"Yeah, so, it's an all-night grad, and it's dry, so I won't be home."

"I heard about that. Dry."

"It's stupid."

"Don't tell Mom, but if you need any beer, I can get some for you."

Ken's eyes did not light up with sudden hope.

"Well, we've kind of already got that-" 
"Okay, okay. I'll come home early from work, get dressed, and see you at the conference centre for the family part at five thirty."

"Yeah," said Ken, still shifting around and looking in the mirrors. "Five thirty."

BRIAN TUMBLED FROM HIS TRUCK'S SEAT onto the road. He landed on his left ribs and couldn't breathe for a few seconds and wondered if he'd somehow killed himself. Winded, bleeding still. Embarrassed that the elk had seen him fall like that. His left shoulder felt wrong. A slowmo vibration went through his skull. There was the sense of a kind of ambient déjà vu about nothing in particular. Was it a concussion? Just surprise. He was surprised. He rolled to his knees, braced on the fender to stand. His body felt much too heavy. He didn't know how to identify injury on an elk. Internal damage. Where was his headlamp? It was day, but he wanted it.

Brian walked a loose zigzag over to the elk, stopped short of its back legs. What an enormous creature. The elk had this chunked breathing, a deep segmented sound in its chest. A human could never make this sound. What was the right thing? No gun in the truck. No knife. That would be pretty hard to explain anyway. There was a tire iron in the box. There was the truck itself if it could still move.

"What are you doing out here?" he said, not really hearing himself. "You fucking elk. You went and got yourself killed."

Dizzy, he sat. Ken's graduation. He had to get ready, suit and tie, smiles, moisturized handshakes. Mai would be with all her little friends being crazy with the cell phones and the cool sneakers. Esna and Mai were getting their hair done in town. They were organized. Ken was at the school already. Thank God. Thank God. Just an accident.

And this was the Seventh. If he did it. Was it the seventh? There was the one, and those others. Was it the seventh?

A station wagon drove by, slowed, sped up. No one would stop.

"So, what's it going to be? Tire iron? I don't want that and you don't want that. Does the truck even work? You see that steam coming from under the hood? That's bad." 
The elk continued its heavy, shallow breathing and didn't respond. Not long now. A broken back. It probably had a broken back. Things without broken backs kicked.

He sat and waited for something to happen, to crystallize. Ten minutes, fifteen, twenty. Ken's graduation. Did he have a phone? He didn't have it on him. The trip home was to get the phone and his nice suit. No cars, no trucks, no nothing. Wind.

"You know what?" he said to the elk. "We're both toast."

Dizzy again. He tried to blink it away. Did that work?

"You know what else, elk?" he shouted. "You know what else? Someone's coming to help you soon. A big man. Enormous. He's coming. He's got his pack and he can walk right over trucks and trees and electric wires. He's coming. We'll wait it out. Right now, let's do it. He'll show.' 